\title{
ANALYSIS OF THE TECHNICAL REGULATION STATE OF COSMETIC PRODUCTS TURNOVER IN UKRAINE
}

\author{
Iryna Kazakova ${ }^{1}$, Viacheslav Lebedynets ${ }^{2}$ \\ ${ }^{1}$ Quality Management Department, National University of Pharmacy, Kharkiv, Ukraine \\ quality@nuph.edu.ua \\ ORCID: http://orcid.org/0000-0001-8966-8039 \\ ${ }^{2}$ Quality Management Department, National University of Pharmacy, Kharkiv, Ukraine \\ v.o.lebedynets@gmail.com \\ ORCID: http://orcid.org/0000-0003-1676-0592
}

A BS TR ACT

Article history:

Received date 06.04.2020

Accepted date 21.04.2020

Published date 30.04.2020

Section:

Pharmacology, Toxicology and

Pharmaceutics

D O I

$10.21303 / 2313-8416.2020 .001279$

KE Y W ORD S

cosmetics

medicinal cosmetics

cosmetic products

technical regulation

state supervision

quality management systems
The object of research is the state regulation of the turnover of cosmetic products and some aspects of their implementation in Ukraine.

Investigated problem. The issue of import substitution of Ukrainian cosmetic products and the increase in their production and sales in the Ukrainian and foreign markets is an urgent reason for the dynamic development of the cosmetic industry and the diversification of its traditional forms and directions of application. The solution to these problems mainly depends on the level of technical regulation by the state and requires proper legislative support in accordance with the requirements of international standards and EU directives. The main scientific results. The foreign experience of regulatory support and state regulation of the turnover of cosmetic products (CP) is summarized. The problems of technical regulation of cosmetic and medicinal cosmetics in Ukraine are identified. An addition to the draft national technical regulation for cosmetic products is proposed and recommendations for its rational use are given. The prospects of introducing quality management systems at enterprises engaged in activities at all stages of the CP life cycle are determined. Innovative technological product. A model has been developed to improve the current regulatory and technical framework governing the CP turnover in Ukraine, and an algorithm for its implementation is presented. The relevance of methods and means of ensuring the quality, safety and effectiveness of $\mathrm{CP}$ by introducing quality management systems at all stages of its life cycle is determined.

The scope of the innovative technological product. The developed proposals are recommended for implementation in the system of state regulation of the $\mathrm{CP}$ turnover in order to ensure its quality, effectiveness and safety for the health of consumers.

(C) The Author(s) 2020. This is an open access article under the CC BY license http://creativecommons.org/licenses/by/4.0).

\section{Introduction}

\section{1. The object of research}

The object of research is the regulatory processes for the turnover of cosmetic products and the technology for their implementation in Ukraine and abroad.

\section{2. Description of the problem}

The importance and priority of technical regulation of the $\mathrm{CP}$ turnover of cosmetic products in Ukraine is determined by the Association Agreement between Ukraine and the EU [1]. The cosmetic industry of Ukraine is characterized by high prospects for increasing competitiveness and facilitating import substitution. Along with this, ensuring compliance with the laws of the EU countries is a necessary requirement for its effective promotion in the Ukrainian and foreign markets. Now significant attention of scientists and practitioners is paid to the development of the perfumery and cosmetics industry [2, 3], to ensure the CP quality and safety $[4,5]$. The issues of technical regulation of CP turnover are currently not regulated in Ukraine and require research on its compliance with international practice.

\section{3. Suggested solution to the problem}

In order to formulate proposals for ensuring proper technical regulation of CP turnover in Ukraine, it is considered advisable to study the experience of countries with a large cosmetic market 
and a developed state system for regulating the turnover of such products, as well as conduct a comparative analysis of the legislative framework governing CP turnover in Ukraine and other countries. Based on the results of the study, develop recommendations on the introduction of effective approaches to the practice of regulating the CP turnover in Ukraine.

The aim of research is to develop practical recommendations on the technology for improving and implementing regulatory documents in Ukraine in accordance with international requirements in the field of CP turnover.

\section{Materials and methods}

Scientific publications, the Ukrainian and foreign legislative framework on the regulation of turnover of pharmaceutical products, electronic databases of the State Register of Medicines of Ukraine, the weekly Pharmacy and the Compendium directory, and the results of our own research are used as information materials. Methods are applied: analytical, comparative, content analysis and generalization of information.

\section{Results}

The experience of regulating CP turnover in the EU countries, as well as in the USA, Japan, India and China, is studied. The main regulatory documents governing the $\mathrm{CP}$ turnover in these countries, where there is a high level of development of the cosmetics industry, are analyzed [6-10]. The research results are given in Table $\mathbf{1}$.

Table 1

Analysis of the legislative regulation of CP turnover in the countries of the world

\begin{tabular}{|c|c|c|}
\hline Country & Regulatory documents & Status and purpose of the document \\
\hline 1 & 2 & 3 \\
\hline \multirow{5}{*}{$\begin{array}{l}\text { EU } \\
\text { countries }\end{array}$} & $\begin{array}{c}\text { Regulation (EC) No } 1223 / 2009 \text { of the European } \\
\text { Parliament and of the European Council (REACH) on } \\
\text { cosmetic products, } 2009\end{array}$ & Basic regulatory framework \\
\hline & $\begin{array}{c}\text { Commission decision } 2013 / 674 / \text { EU on the implementa- } \\
\text { tion of the guidelines of Regulation (EU) } \\
\text { No. } 1232009,2013 \text {. }\end{array}$ & Cosmetic safety report implementation guide \\
\hline & Commission Regulation (EU) No 655/2013, 2013. & $\begin{array}{l}\text { Establishment of general criteria for substantiating require- } \\
\text { ments for cosmetic products }\end{array}$ \\
\hline & Commission Report to the European Parliament, 2016 & $\begin{array}{c}\text { Generalization of CP requirements based on general condi- } \\
\text { tions in the field of cosmetics }\end{array}$ \\
\hline & Cosmetic Requirements Paper, 2017 & $\begin{array}{l}\text { Regulation on the Application of Regulation (EU) No } \\
\qquad 1223 / 2009\end{array}$ \\
\hline \multirow{4}{*}{ USA } & $\begin{array}{l}\text { Federal Law on Food, Medicines and } \\
\text { Cosmetic Products, } 1938\end{array}$ & Basic regulatory framework \\
\hline & Cosmetic Safety Amendment Act, 2012 & $\begin{array}{l}\text { Regulates requirements for: registration of Ukrainian and } \\
\text { foreign enterprises for the CP production; reporting any } \\
\text { serious and unexpected adverse effects associated with } \\
\text { the CP use }\end{array}$ \\
\hline & & $\begin{array}{l}\text { Regulates requirements for: CP labeling; CP safety or } \\
\text { ingredients in their composition; list of ingredients: (1) } \\
\text { prohibited and restricted for use (2) safe, used without } \\
\text { restriction (3) priority assessment; Good Manufacturing }\end{array}$ \\
\hline & $\begin{array}{c}\text { Law on the Safety of Cosmetics and Personal Care } \\
\text { Products, } 2013\end{array}$ & $\begin{array}{l}\text { Practices the procedure for recalling or terminating } \\
\text { the CP distribution that are falsified, mislabeled or } \\
\text { otherwise violates FDA requirements; the procedure } \\
\text { for reporting serious side effects of minimizing } \\
\text { the use of animals for testing CP and ingredients in their } \\
\text { composition }\end{array}$ \\
\hline
\end{tabular}


Continuation of Table 1

\begin{tabular}{lll}
\hline 1 & 2 & 3 \\
\hline
\end{tabular}

Regulations concerning the Hygiene Supervision over Cosmetics), 1989

Cosmetic Supervision and Administration Regulation (CSAR), adopted by the State Council of China on 03.01.2020

Hygienic Standard for Cosmetics, 2007

GB 5296.3-2008 General labeling for cosmetics, 2008

Requirements for Application and Acceptance of Administrative Licensing for Cosmetics, 2009

Guide to the Naming of Cosmetics, 2010

Requirements for Cosmetic Administrative Licensing Testing, 2010

Guidance on Application and Review of New Cosmetic Ingredient, 2011

China

Guidance on Application and Review of Children's Cosmetics, 2012

Requirements for Filing of Ukrainian Non-special Use Cosmetic Products, 2013

Hygiene standard for cosmetics, 2015 (revised in 2016)

Inventory of Existing Cosmetic Ingredients in China, 2014

Guidelines for the registration and harmonization of personal cosmetics (home-made), 2016

Guidelines on the procedure for registration and approval of import CP of non-special purpose, 2016

Guidelines on the procedure for registration and approval of imported CP of special purpose, 2016

The Administrative Measures on the Inspection and Quarantine and Supervision of Chinese Imported and Exported Cosmetics, 2011

Director General of the Pharmaceutical Affairs Bureau Notification N.1339, 1980

Law on Pharmaceutical Activities No. 96, 2002

Japan Communication from the Bureau of Drug and Food Safety, Ministry of Health, Labor, and Social Welfare of Japan, 2002

Law on Ensuring the Quality, Efficiency and Safety of Medicines and Medical Equipment, 2016
Basic regulatory framework

Good Manufacturing Practice Standard (GMP) for CP production

Regulation of CP labeling requirements

Regulates the requirements for the registration dossier for imported $\mathrm{CP}$, personal $\mathrm{CP}, \mathrm{CP}$ of special purpose and new $\mathrm{CP}$ ingredients

Regulation of the requirements for the $\mathrm{CP}$ name

Regulation of requirements for testing imported CP products, personalized special cosmetics and new cosmetic ingredients

Regulating registration requirements for new cosmetic ingredients

Regulation of registration requirements for cosmetic products for children

Regulation of requirements for personal cosmetics (homemade) for non-special purposes

Regulation of CP safety requirements and technical standards

Regulation on registration of cosmetic ingredients

Regulation of requirements for the design, review and approval of special-purpose personal cosmetics

Regulation of requirements for the design, review and approval of imported non-special purpose CP

Regulation of requirements for registration, consideration and approval of imported special purpose $\mathrm{CP}$

Regulation of requirements for import and export CP

Standard for cosmetic products

Basic regulatory framework

Determination of the status of cosmetics

Basic regulatory framework 
Continuation of Table 1

\begin{tabular}{|c|c|c|}
\hline 1 & 2 & 3 \\
\hline \multirow{12}{*}{ Japan } & $\begin{array}{l}\text { Rules for the application of the Law on ensuring the } \\
\text { quality, effectiveness and safety of medicines and medi- } \\
\text { cal equipment, } 2016\end{array}$ & Basic regulatory framework \\
\hline & $\begin{array}{l}\text { Procedure for the implementation of the Law on ensur- } \\
\text { ing the quality, effectiveness and safety of medicines } \\
\text { and medical equipment, } 2018\end{array}$ & Basic regulatory framework \\
\hline & Cosmetic Standards, 2001 & $\begin{array}{l}\text { Regulation of the requirements of ingredients in the CP } \\
\text { composition }\end{array}$ \\
\hline & $\begin{array}{l}\text { Standards for advertising drugs, quasi-drugs, cosmetics } \\
\text { and medical equipment, } 2002\end{array}$ & $\begin{array}{l}\text { Regulation of requirements for advertising of drugs, qua- } \\
\text { si-drugs, cosmetics and medical equipment }\end{array}$ \\
\hline & Quasi-drug ingredient standards, 2013 & Regulation of requirements for ingredients in quasi-drugs \\
\hline & $\begin{array}{l}\text { Procedure for submitting documents for verification of } \\
\text { GMP compliance, } 2014\end{array}$ & Regulation of CP production requirements \\
\hline & $\begin{array}{l}\text { Requirements for the submission of an application for } \\
\text { marketing approval quasi-drugs, } 2014\end{array}$ & Regulation of quasi-drug licensing requirements \\
\hline & Good Quality Practice, 2014 & Regulation of CP production requirements \\
\hline & Biological Ingredient Standards, 2014 & Regulation of the requirements for the $\mathrm{CP}$ ingredients \\
\hline & GMP Standard 2014 & Regulation of CP production requirements \\
\hline & $\begin{array}{c}\text { The accreditation standard of a foreign manufacturer of } \\
\text { quasi-drugs, } 2015\end{array}$ & Regulation of quasi-drug licensing requirements \\
\hline & Good Mindfulness Practice, 2015 & Regulation of $\mathrm{CP}$ production requirements \\
\hline
\end{tabular}

Drugs and Cosmetics Act, 1940, supplemented by the List of Rules (Drug and Cosmetic Rules), 1945

Guidelines for importing cosmetics, 2013

India

Clarification regarding the import and registration of cosmetics, 2015

Classification of Cosmetic Raw Materials and Additives, 2016
Regulation of the import, production, distribution and sales of medicines and cosmetics

Regulation of registration requirements for imported cosmetics

Clarification of 2013 Guidelines

Regulation of the list of substances that are prohibited and restricted for use in cosmetics

According to the results of studies, in countries with a developed cosmetic market, significant attention from the state is paid to the quality, safety and effectiveness of CP. All stages of the product life cycle are regulated by the relevant regulatory legal acts (for example, criteria, methods for assessing and monitoring the quality, safety and effectiveness of $\mathrm{CP}$ ).

If there is a declaration of a therapeutic effect in the $\mathrm{CP}$, their status is defined as "medicinal cosmetics" (USA, India), "quasi-cosmetics" (Japan), and "special cosmetics" (China). In this case, the legislator regulates the need to prove the therapeutic and cosmetic effect of the product by determining its compliance with the requirements of certain standards.

Special requirements for the CP safety are distinguished by EU countries, in whose territory the CP turnover is regulated by Regulation No. 1223/2009 of the European Parliament and the European Council for Cosmetic Products $[9,10]$. The objects of systematic monitoring on the part of the authorized bodies are all links of $\mathrm{CP}$ turnover on the market. 
An important area of industry control over CP in the world is cosmetological supervision (cosmetovigilance) - monitoring the $\mathrm{CP}$ safety in the process of their practical application. The process of monitoring the results of the use of products involves the interaction of the responsible person of the manufacturer, distributor, medical/pharmaceutical representative and the consumer of $\mathrm{CP}$.

The information base on undesirable effects resulting from the CP use is generally accessible and forms a system of safe and high-quality cosmetic market. If there is a serious risk to the health of consumers, which requires urgent action, the authorized body will take the necessary measures to prohibit or restrict sales of CP in the market or to extract such products from points of sale.

The key to the correct operation of all parts of the CP turnover system is the implementation of quality management principles in accordance with the requirements of relevant good practices (development, production, laboratory research, storage, transportation, etc.) and quality system standards.

In Ukraine, regulation of CP turnover is determined by a number of regulatory legal acts, which should be investigated in accordance with the legal status of this category of products.

According to the requirements of DSTU 2472:2006 "Perfume and cosmetic products. Terms and definitions", CP status is defined in Ukraine, and according to the Law of Ukraine "On Medicines" dated 04.04.1996 No. 123/96-BP - the status of medicinal cosmetic products (MCP). A combination of cosmetic and medicinal properties is MCP characteristic.

An analysis of the features of technical regulation of the $\mathrm{CP}$ and MCP turnover in accordance with the requirements of current regulatory documents is given in Table 2.

Table 2

Analysis of technical regulation of the $\mathrm{CP}$ and MCP turnover in Ukraine

\begin{tabular}{|c|c|c|}
\hline \multirow{2}{*}{$\begin{array}{l}\text { The stages of product } \\
\text { turnover regulated by a } \\
\text { normative legal act }\end{array}$} & \multicolumn{2}{|c|}{ Normative legal acts of Ukraine } \\
\hline & Medicinal cosmetic products & Cosmetic products \\
\hline 1 & 2 & 3 \\
\hline $\begin{array}{l}\text { Creation, registration, } \\
\text { production, quality control } \\
\text { and implementation (in the } \\
\text { conditions of pharmacies) }\end{array}$ & $\begin{array}{c}\text { The Law of Ukraine «On Medicines» dated } \\
04.04 .1996 \text { No. 123/96-BP }\end{array}$ & $\begin{array}{c}\text { The order of the Ministry of Health dated } \\
06.07 .2012, \text { No. } 498 \text { "On approval of the } \\
\text { List of goods entitled to purchase and sell } \\
\text { pharmacy institutions and their structural } \\
\text { divisions }\end{array}$ \\
\hline Retail sales & - & $\begin{array}{c}\text { Order of the Ministry of Economy of Ukraine } \\
\text { of April 19, } 2007 \text { No. } 104 \text { "On the Approval } \\
\text { of the Rules for Retail Trade in Non-Food } \\
\text { Products" }\end{array}$ \\
\hline Registration & $\begin{array}{l}\text { Regulation of the Pharmacological Committee of } \\
\text { the Ministry of Health of } \\
\text { Ukraine No. } 3 \text { dated } 23 \text { 05. } 96 \text { g. "On registra- } \\
\text { tion and the procedure for issuing permits for the } \\
\text { import and use of foreign and Ukrainian medical } \\
\text { cosmetics" } \\
\text { Order of the Ministry of Health of Ukraine dated } \\
04.01 .2013 \text { No. } 3 \text { "On Amendments to the Order } \\
\text { of the Ministry of Health of Ukraine dated August } \\
26,2005 \text { No. } 426 \text { and invalidation of certain } \\
\text { orders of the Ministry of Health of Ukraine on the } \\
\text { registration of medicines" Order of the Ministry } \\
\text { of Health of Ukraine No. } 500 \text { of } 20.07 .2006 \text { "On } \\
\text { approval of the List of names of dosage forms and } \\
\text { packaging for medicines" }\end{array}$ & $\begin{array}{c}\text { Resolution of the Chief State Sanitary Doctor } \\
\text { of Ukraine «State Sanitary Rules and Safety } \\
\text { Standards for Products of the Perfume and } \\
\text { Cosmetic Industry» dated } \\
\text { July 01. 07. } 1999 \text { No. } 27\end{array}$ \\
\hline
\end{tabular}




\section{Continuation of Table 2}

1
2
Sanitary and hygienic examination at the stages of development, production, transportation, storage, sale and professional use in the provision of hairdressing services to the population

epidemic well-being of the population» dated
24.02.1994 No. 4004-XII Resolution of the
Chief State Sanitary Doctor of Ukraine «State
sanitary rules and safety standards for products
of the perfumery and cosmetics industry» dat-
ed 01.07.1999 No. 27 Order of the Ministry of
Health of Ukraine «On approval «Temporary
procedure for conducting state sanitary and
hygienic examination» of 09.10 .2000 No. 247

According to the results of the analysis of the Ukrainian legislative base, in the consumer market of Ukraine there are two categories of products - CP and MCP, the legislative regulation of which has certain features. The MCP turnover is regulated by general requirements in the field of healthcare and is controlled by the Ministry of Health $(\mathrm{MH})$ of Ukraine. CP is defined as a category of non-food products, the turnover of which is controlled by the State Service for Food Safety and Consumer Protection.

\section{Discussion}

According to the results of the study, it was established that international experience in regulating the turnover of cosmetic products proves the need for a systematic approach to ensuring its quality, safety and effectiveness. In a number of countries, such as the USA, Japan, India, and China, categories of cosmetic products that can have medicinal properties are defined, and in proving, along with cosmetic, a therapeutic effect [6-10]. The analysis of regulatory documents governing the CP turnover in Ukraine indicates that the requirements for their quality and safety do not meet international standards, outdated regulatory and technical documents continue to apply. The current regulatory framework does not provide for the regulation of the processes of creation, research, registration, post-marketing control of cosmetic products. CP sanitary-hygienic examination procedure does not meet international standards. For MCP there is no regulation of the criteria and methods for assessing cosmetic effectiveness [11, 12]. These factors do not contribute to the harmonization of industry legislation with the requirements of European directives and may pose a potential threat to consumer health.

Thus, the Ukrainian legislative framework requires urgent system improvement, but the necessary changes are taking place very slowly. In fulfillment of Ukraine's obligations regarding the implementation of EU legislation into national legislation, the Ministry of Health of Ukraine back in 2013 developed a draft Technical Regulation for Cosmetic Products (hereinafter - Regulation). The draft Regulation is again posted on the website of the Ministry of Health of Ukraine on January 23, 2020 for public discussion. The analysis of the document [13] shows the need for its specific supplement in order to comply with European standards and current trends in the development of the cosmetics industry. In particular, it is recommended that the requirements for state market supervision be specified, namely: monitoring compliance with the principles of good practice in organizing production by industry enterprises. It should also include a requirement for the competent authority to apply the necessary measures to prohibit or limit the entry of CP to the market or to withdraw them from sales on the basis of the facts of non-compliance. The following should be considered the conditions for the above actions: the presence of a serious risk to the health of consumers; neglect by the responsible person of appropriate measures for a specified period of time.

For the effective implementation of the Regulation, the question arises of the implementation of its requirements in Ukraine, namely: the creation of a Ukrainian regulatory framework, the adaptation of documents and the definition of competent organizations that will ensure control over their implementation. Based on the analysis of the current national legislative framework and the experience of foreign countries in regulating the CP turnover, recommendations are developed for the implementation of the Regulations, the implementation algorithm of which is shown in Fig. 1. 


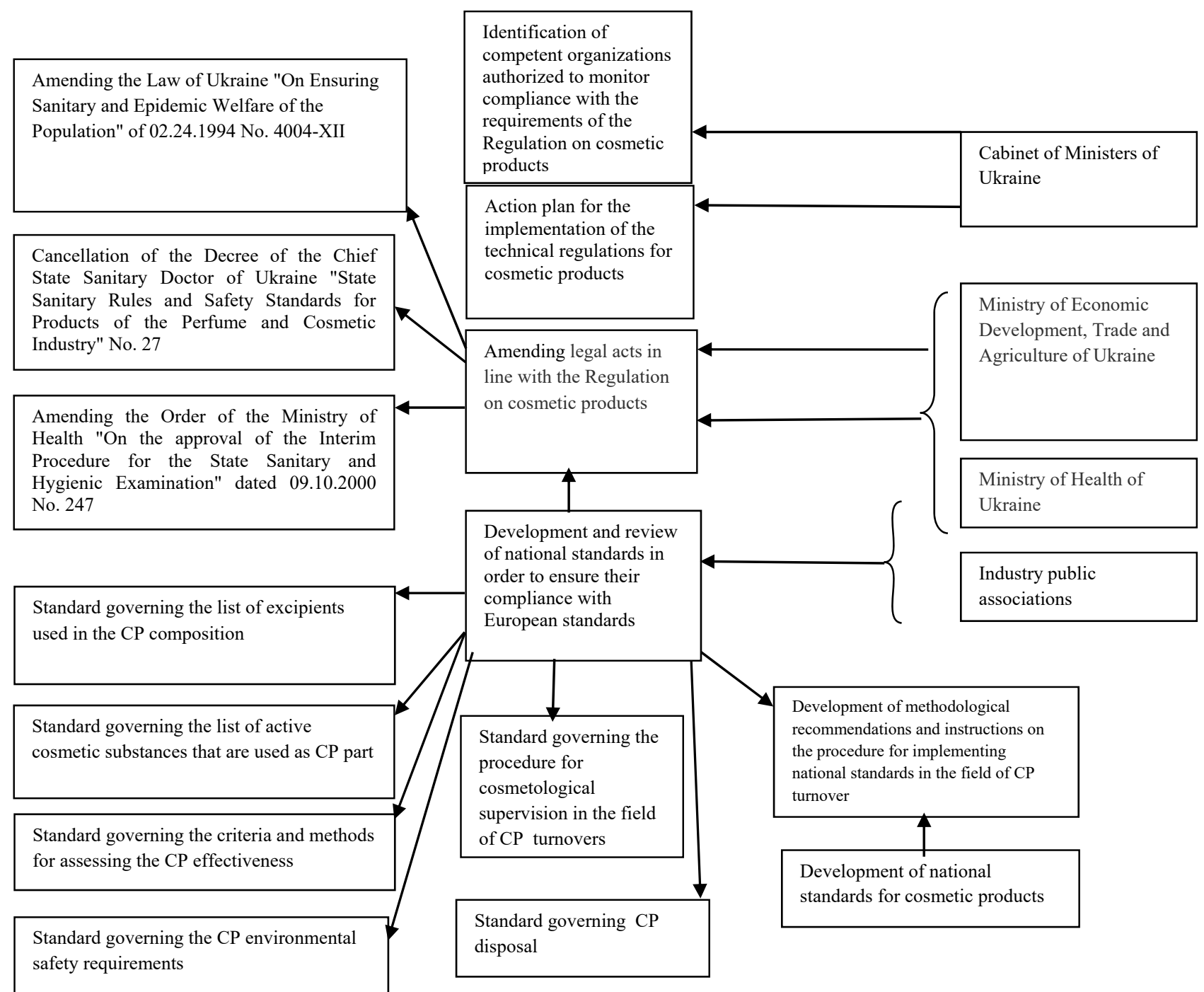

Fig. 1. Algorithm for the implementation of the provisions of the Regulation on cosmetic products

It can be argued that for the implementation of the Regulation it is necessary to apply a complex of multi-vector management actions, it requires combining the efforts of both authorized state bodies and industry public organizations, as well as all participants in the cosmetic market as a whole. The use of these technologies for the implementation of the Regulation is aimed at its effective implementation in order to ensure compliance with international standards.

\section{Conclusions}

The peculiarities of regulating the turnover of cosmetic and medicinal cosmetic products in different countries of the world are established. International experience of technical regulation of the $\mathrm{CP}$ turnover are investigated, features of legislative support for the quality, safety and effectiveness of $\mathrm{CP}$ and $\mathrm{MCP}$ in Ukraine are described. Inconsistencies of the existing Ukrainian regulatory framework for the technical regulation of the CP turnover with international approaches are identified. An analysis of the draft national technical regulation for cosmetic products is carried out, recommendations are given for its improvement and an algorithm for implementing its provisions.

The problems of import substitution of Ukrainian CP and the increase in their production and sales in the Ukrainian and foreign markets are relevant in the context of the dynamic development of the cosmetics industry. The solution to this problem directly depends on the level of technical regulation of $\mathrm{CP}$ turnover and requires proper legislative support in accordance with the requirements of international and European standards and directives.

Given the foregoing, promising is the continuation of work on the development of regulatory documents governing the standardization of cosmetic products, given the experience of interna- 
tional technical regulation and the development of the modern cosmetic market. The use of quality management systems at all stages of $\mathrm{CP}$ turnover allows to provide a systematic approach to their standardization and quality control, to guarantee consumers the proper efficiency and safety of products in accordance with international standards.

\section{References}

[1] Heits, V. M., Ostashko, T. O. (Eds.) (2016). Implementatsiia Uhody pro asotsiatsiiu mizh Ukrainoiu ta YeS: ekonomichni vyklyky ta novi mozhlyvosti. Kyiv, 184.

[2] Baitsar, R. I., Kordiiaka, Yu. M. (2015). Aktualni problemy ta perspektyvy rozvytku kosmetychnoi haluzi. Lviv, 6.

[3] Burd, N. B., Heorhiiants, V. A., Polovko, N. P., Hryzodub, O. I. (2015). Likuvalna kosmetyka v Ukraini: realii ta perspektyvy. Farmatsevtychnyi zhurnal, 6, 19-28.

[4] Heorhiievskyi, H. V. (2016). Osnovni tendentsii u harmonizatsii vymoh vyrobnytstva i kontroliu yakosti kosmetolohichnykh zasobiv v Ukraini z vymohamy YeS u svitli chlenstva Ukrainy v Yevropeiskii Farmakopei. Farmakom, 4, $21-28$.

[5] Kovalova, O. M., Tsyhulova, O. M., Shumilo, O. M., Dieieva, O. O. (2016). Bezpeka kosmetychnykh tovariv v Ukraini. Medyko-pravovi aspekty ta suchasna koniunktura na vnutrishnomu rynku. Kyiv: FOP «Klymenko», 447.

[6] U.S. and EU Cosmetics Regulation. Available at: https://cosmeticsinfo.org/cosmetics-regulation Last accessed: 01.01.2020

[7] Romanowski, P. (2018). Cosmetic Regulations Around The World. Chemists Corner. Available at: https://chemistscorner.com/ cosmetic-regulations-around-the-world/ Last accessed: 04.03.2020

[8] Ruhela, M., Nagar, L., Gupta, A., Popli, H. (2018). Cosmetics: Regulatory and market scenario for us and India. The Pharma Innovation Journal, 7 (6), 164-169. Available at: http://www.thepharmajournal.com/archives/2018/vol7issue6/PartC/7-6-3-701.pdf

[9] Nobile, V. (2016). Guidelines on Cosmetic Efficacy Testing on Humans. Ethical, Technical, and Regulatory Requirements in the Main Cosmetics Markets. Journal of Cosmetology \& Trichology, 2 (1). doi: http://doi.org/10.4172/2471-9323.1000107

[10] Regulation (EC) No 1223/2009. European parliament and of the council of 30 November 2009 on cosmetic products (2009). Official Journal of the European Union, L 342/59-L 342/209. Available at: https://eur-lex.europa.eu/LexUriServ/LexUriServ. do?uri=OJ:L:2009:342:0059:0209:en:PDF

[11] Lebedynets, V. O., Kazakova, I. S. (2018). Analiz funktsionuvannia derzhavnoi systemy otsinky yakosti ta bezpeky kosmetychnykh zasobiv v Ukraini. Advances of science. Karlovy Vary - Kyiv, 163-166.

[12] Lebedynets, V. O., Kazakova, I. S., Kazakova, V. S. (2018). Suchasni pidkhody do standartyzatsii likarskykh kosmetychnykh zasobiv v Ukraini. Upravlinnia yakistiu v farmatsii. Kharkiv, 221-229.

[13] Rehuliuvannia kosmetychnoi produktsii v Ukraini: opryliudneno doopratsovanu postanovu (2020). Available at: https:// www.apteka.ua/article/530929 Last accessed: 07.03.2020 